\title{
PROBLEMATIKA PEMBELAJARAN BAHASA JEPANG OLEH GURU NON KEPENDIDIKAN BAHASA JEPANG DI SMA NEGERI 1 BANJAR
}

\author{
I. K. D. Ariasta ${ }^{1}$, G. S. Hermawan ${ }^{2}$, I. W. Sadyana ${ }^{3}$ \\ ${ }^{123}$ Jurusan Pendidikan Bahasa Jepang, Universitas Pendidikan Ganesha, Singaraja \\ e-mail: komang.dika.ariasta@undiksha.ac.id, satya.hermawan@undiksha.ac.id, wayan.sadyana@undiksha.ac.id
}

\begin{abstract}
Abstrak
Penelitian ini bertujuan untuk mendeskripsikan problematika dalam pembelajaran bahasa Jepang pada perencanaan, pelaksanaan, dan evaluasi pembelajaran bahasa Jepang oleh guru non kependidikan bahasa Jepang. Subjek penelitian ini adalah guru bahasa Jepang. Pengumpulan data dilakukan dengan metode observasi, wawancara, dan studi dokumen. Data hasil penelitian dianalisis menggunakan metode deskriptif kualitatif. Hasil penelitian menunjukkan bahwa guru bahasa Jepang mengalami problematika pembelajaran (1) pada tahap perencanaan pembelajaran yaitu model pembelajaran, menjelaskan materi, dan sumber ajar, (2) pada tahap pelaksanaan pembelajaran yaitu memanajemen waktu dan kegiatan proses pembelajaran. dan (3) pada tahap evaluasi pembelajaran yaitu penilaian proses dan penilaian sikap.
\end{abstract}

Kata kunci: problematika, pembelajaran, bahasa Jepang

\section{要旨}

本研究の目的は、非日本語教育の教師による計画、実施、評価で本語学習の障害を 明らかにすることである。調査協力者はバンジャル第一国立高校の日本語教師であ る。調査方法は、観察、インタビュー及び文献調査である。収集したデータは定性 的記述法により分析した。結果は日本語の教師による日本語学習の障害は (1) 授業計 画は学習モデル、教材の説明、および教材、(2) 授業実施は時間管理と学習プロセス 活動、（3)評価はプロセス評価と態度評価を明らかにすることである。

キーワード：障害、学習、日本語

\section{Pendahuluan}

Pelaksanaan pendidikan sebagaimana diamanatkan dalam Undang-Undang Nomor 20 Tahun 2003 tentang sistem pendidikan nasional memiliki peran yang sangat penting sebagai pendukung utama dalam pembangunan. Menurut Undang-Undang Sistem Pendidikan Nasional No. 20 Tahun 2003 menyatakan bahwa pendidikan adalah usaha sadar untuk menyiapkan peserta didik melalui kegiatan bimbingan, pengajaran, dan atau latihan bagi peranannya di masa yang akan datang. Pelaksanaan pendidikan diharapkan dapat mewujudkan proses berkembangnya kualitas peserta didik sebagai generasi penerus bangsa. Tanpa bermaksud mengecilkan kontribusi komponen yang lainnya, komponen tenaga kependidikan atau guru merupakan salah satu faktor yang sangat esensi dalam menentukan kualitas peserta didiknya.

Pendidik atau guru merupakan salah satu unsur di bidang kependidikan yang harus berperan secara aktif dan menempatkan kedudukannya sebagai tenaga profesional sesuai dengan tuntutan masyarakat yang semakin berkembang. Dalam hal ini guru tidak sematamata sebagai pengajar yang melakukan transfer ilmu pengetahuan, tetapi juga sebagai pendidik yang melakukan transfer nilai-nilai sekaligus sebagai pembimbing yang memberikan pengarahan dan menuntun siswa dalam belajar. Kelengkapan dari jumlah tenaga pengajar dan kualitas dari guru tersebut akan memengaruhi keberhasilan siswa dalam belajar yang berujung pada peningkatan mutu pendidikan. Oleh karena itu, guru dituntut profesional dalam menjalankan tugasnya.

Usaha untuk menciptakan guru yang profesional, pemerintah telah membuat aturan persyaratan untuk menjadi guru. Dalam pasal 8 Undang-Undang No.14 tahun 2005 tentang 
guru dan dosen menyebutkan bahwa guru wajib memiliki kualifikasi akademik, kompetensi, sertifikat pendidik, sehat jasmani dan rohani, serta memiliki kemampuan untuk mewujudkan tujuan pendidikan nasional. Namun dalam kenyataannya masih sedikit guru yang memenuhi syarat tersebut. Setiap usaha pendidikan seperti penggantian kurikulum, pengembangan metode mengajar, penyediaan sarana dan prasarana hanya akan berarti jika melibatkan guru. Berdasarkan Undang-Undang No. 14 Tahun 2005 Bab IV pasal 20 (a) tentang guru dan dosen menyatakan bahwa standar prestasi kerja guru dalam melaksanakan tugas keprofesionalannya, guru berkewajiban merencanakan pembelajaran, melaksanakan proses pembelajaran yang bermutu serta menilai dan mengevaluasi hasil pembelajaran. Tugas pokok guru tersebut yang diwujudkan dalam kegiatan belajar mengajar merupakan bentuk kinerja guru. Peningkatan kinerja guru akan berpengaruh pada peningkatan kualitas output SDM yang dihasilkan dalam proses pendidikan dan pembelajaran. Kualitas pendidikan dan lulusan sering kali dipandang tergantung kepada peran guru dalam pengelolaan komponenkomponen pengajaran yang digunakan dalam proses belajar mengajar yang menjadi tanggung jawabnya. Untuk dapat mencapai hasil belajar yang optimal tentunya guru harus memiliki dan menampilkan kinerja yang maksimal selama proses belajar mengajar dengan menyesuaikan perkembangan ilmu pengetahuan dan teknologi.

Berdasarkan Peraturan Pemerintah (PP) Nomor 74 Tahun 2008 tentang guru, bahwa seorang guru harus wajib memiliki 4 (empat) kompetensi, salah satu kompetensi yang wajib dimiliki oleh guru adalah kompetensi profesional. Kompetensi profesional yang dimaksud dalam hal ini merupakan kemampuan guru dalam penguasaan materi pelajaran secara luas dan mendalam. Penguasaan materi secara luas dan mendalam dalam hal ini termasuk penguasaan kemampuan akademik lainnya yang berperan sebagai pendukung profesionalisme guru. Kemampuan akademik tersebut antara lain, memiliki kemampuan dalam menguasai ilmu, jenjang dan jenis pendidikan yang sesuai. Guru yang profesional perlu memiliki kemampuan untuk menggali informasi kependidikan dan bidang studi dari berbagai sumber, termasuk dari sumber elektronik dan pertemuan ilmiah, serta melakukan kajian atau penelitian untuk menunjang pembelajaran yang mendidik. Jika mengacu pada empat kompetensi yang harus dikuasai guru menurut kebijakan pemerintah, maka salah satu kompetensi yang spesifik dan terkait langsung dengan tugas guru adalah kompetensi profesional. Apabila kompetensi tersebut tidak dimiliki oleh seorang guru dalam pembelajaran maka akan memicu problematika atau permasalahan dalam pembelajaran yang nantinya akan menghambat proses pembelajaran yang diberikan khususnya dalam hal ini pada pembelajaran bahasa Jepang.

Berdasarkan fakta dilapangan pembelajaran bahasa Jepang kini telah diberikan pada jenjang sekolah menengah atas (SMA) melalui jalur peminatan kelas IBB (IImu Bahasa dan Budaya), namun karena keterbatasan tenaga pendidik bahasa Jepang sedangkan siswa peminat kelas IBB semakin meningkat sehingga mata pelajaran bahasa Jepang diajarkan oleh guru non kependidikan bahasa Jepang untuk memenuhi tuntutan kurikulum. Hal tersebut menyebabkan guru mengalami beberapa problematika/permasalahan dalam pembelajaran baik dari segi perancanaan pembelajaran, pelaksanaan pembelajaran, dan evaluasi/penilaian pembelajaran bahasa Jepang karena guru tersebut harus menyesuaikan dengan tuntutan kurikulum 2013.

Hal tersebut didukung dengan penelitian yang dilakukan oleh Roselina (2015) dengan hasil penelitiannya menujukkan bahwa problematika pembelajaran bahasa Indonesia di kelas X TITL 3 SMK Negeri 3 adalah pada kegiatan pendahuluan guru tidak melakukan kegiatan membangun konteks kepada siswa. Pada kegiatan inti pembelajaran, guru tidak menggunakan media sebagai alat bantu dalam pelaksanaan pembelajaran, dan tidak terlaksananya tahapan pembelajaran scientific dengan baik. Selain itu guru tidak melakukan evaluasi langsung setelah pembelajaran berakhir.

Berdasarkan hasil studi pendahuluan yang telah dilakukan di SMA Negeri 1 Banjar dengan teknik wawancara menunjukkan bahwa terdapat problematika dalam pembelajaran bahasa Jepang yang dilaksanakan oleh guru bahasa Jepang di SMA Negeri 1 Banjar yangmana pengampu mata pelajaran bahasa Jepang merupakan pengajar non kependidikan bahasa Jepang. Hal ini menunjukkan adanya ketidaksesuaian antara keahlian 
yang dimiliki dengan bidang ilmu yang diajarkan atau diterapkan di sekolah. Dalam proses pembelajaran meskipun pengajar bukan lulusan kependidikan bahasa Jepang akan tetapi guru sudah mampu menerapkan beberapa strategi pembelajaran seperti ceramah, drill, tanya jawab, seperti pembelajaran yang dilakukan pengajar kependidikan bahasa Jepang. Walaupun tidak dapat dipungkiri dalam proses pembelajaran bahasa Jepang dikelas masih ditemui beberapa problematika yang belum dapat diperbaiki. Bagi guru, penyusunan RPP tidak terlalu mengalami masalah karena pedoman penulisan RPP sudah ada dalam buku pelatihan implementasi kurikulum. Akan tetapi mengalami kendala dalam mengaplikasikan atau menerapkan tahapan pembelajaran scientific yaitu pada proses mengamati, menanya, mengumpulkan informasi, mengasosiasi, dan mengkomunikasikan yang terdapat pada RPP. Selain itu guru juga mengalani kendala dalam melakukan evaluasi pembelajaran. Pengajar harus memberikan evaluasi kepada siswa secara individu, sedangkan pengajar belum memahami cara penilaian dalam kurikulum 2013 yakni menggunakan format penilaian autentik berdasarkan tiga ranah yakni ranah pengetahuan, sikap, dan keterampilan.

Berdasarkan uraian di atas, maka dipandang perlu melakukan penelitian untuk mengetahui problematika pembelajaran bahasa Jepang yang ditinjau dari perencanaan, pelaksanaan, dan evaluasi/penilaian pembelajaran bahasa Jepang oleh guru non kependidikan bahasa Jepang di SMA Negeri 1 Banjar Penelitan ini dilakukan untuk mendeskripsikan problematika apa saja yang dihadapi dalam pembelajaran bahasa Jepang. sehingga dapat digunakan sebagai refleksi untuk memperbaiki kualitas pembelajaran bahasa Jepang pada khususnya dan pendidikan di SMA Negeri 1 Banjar pada umumnya.

\section{Metode}

Penelitian ini mengangkat tentang problematika pembelajaran bahasa Jepang oleh guru non kependidikan bahasa Jepang di SMA Negeri 1 Banjar. Pendekatan yang digunakan dalam penelitian ini adalah kualitatif. Subjek dari penelitian ini adalah guru bahasa Jepang di SMA Negeri 1 Banjar yangmana merupakan guru non kependidikan bahasa Jepang.

Metode pengumpulan data yang digunakan terdiri dari metode observasi, wawancara, dan studi dokumen. Selanjutnya data hasil penelitian yang diperoleh akan dianalisis menggunakan teknik analisi data yaitu analisis sebelum di lapangan, analisis selama masih di lapangan, dan analisis setelah pengumpulan data berakhir. Pengolahan data dilakukan dengan tiga tahap yakni reduksi data, penyajian data, dan verifikasi data/ penarikan kesimpulan (Sugiyono, 2011).

\section{Hasil dan Pembahasan}

Hasil penelitian terkait problematika pembelajaran bahasa Jepang oleh guru non kependidikan bahasa Jepang di SMA Negeri 1 Banjar diperoleh melalui observasi, wawancara, dan studi dokumen. Wawancara dan observasi dilakukan dengan guru non kependidikan bahasa Jepang dan beberapa sampel siswa kelas XI IBB yang terdapat di SMA Negeri 1 Banjar. Pada bagian ini dibahas temuan-temuan yang diperoleh selama penelitian untuk menjawab rumusan masalah yang dipaparkan terkait problematika pembelajaran bahasa Jepang oleh guru non kependidikan bahasa Jepang di SMA Negeri 1 Banjar. Terdapat tiga proses alur pembelajaran yang diteliti yaitu; (1) problematika perencanaan pembelajaran bahasa Jepang guru non kependidikan bahasa Jepang di SMA Negeri 1 Banjar, (2) problematika pelaksanaan pembelajaran guru non kependidikan bahasa Jepang di SMA Negeri 1 Banjar, dan (3) problematika penilaian pembelajaran guru non kependidikan bahasa Jepang di SMA Negeri 1 Banjar.

Problematika perencanaan pembelajaran. Sebelum guru menyelenggarakan pembelajaran bahasa Jepang, guru menyusun perencanaan pembelajaran yang akan dilaksanakan. Pada penelitian ini, data mengenai perencanaan pembelajaran bahasa Jepang diperoleh melalui wawancara, observasi, dan studi dokumen. Berdasarkan wawancara yang telah dilakukan kepada guru pengajar bahasa Jepang non kependidikan bahasa Jepang dan juga didukung dengan hasil observasi diperoleh informasi bahwa sebelumnya guru bahasa Jepang telah menyusun perencanaan terkait pelasaksannan 
pembelajaran yang akan dilaksanakan namun guru mengalami empat problematika dalam perencanaan pembelajaran sebagai berikut;

(1) Problematika metode pembelajaran yaitu guru mengalami problematika dalam menentukan metode atau model pembelajaran yang tepat untuk menjelaskan materi ke siswa, hal ini dikarenakan pemahaman guru tentang berbagai model pembelajaran masih kurang khususnya dalam menerapkan sintak-sintak pembelajaran pada model pembelajaran yang digunakan sehingga guru dalam menerapkan model pembelajaran kurang maksimal.

Guru dalam menyusun perencanaan pelaksanaan pembelajaran guru telah menentukan model pembelajaran scientific namun faktanya ketika guru menerapkannya di dalam kelas guru menggunakan model pembelajaran ceramah saja dan pembelajaran bahasa Jepang didominasi dengan sistem catat. Sehingga proses pembelajaran di dalam kelas relatif moneton dan kurang beragam sehingga membuat peserta didik merasa bosan dalam mengikuti pembelajaran di dalam kelas. Guru tidak menerapkan model pembelajaran scientific dikarenakan guru kurang memahami terkait sintak-sintak pembelajaran pada pembelajaran scientific, disamping itu guru yang diteliti adalah guru non kependidikan bahasa Jepang namun mengajar bahasa Jepang, karena hal tersebut terdapat beberapa materi yang tidak dapat dikuasai dengan baik sehingga guru kesulitan dalam menentukan model pembelajaran yang sesuai. Selain itu ketika guru menentukan model pembelajaran scientific yang menuntut siswa untuk harus berpikir kritis melalui kegiatan belajar diskusi (diskusi kelompok atau diskusi dengan teman sebangku) namun siswa memanfaatkan kegiatan diskusi tersebut untuk mengobrol, sehingga kegiatan diskusi tidak berjalan dengan baik dan materi yang seharusnya diselesaikan dalam 1 kali pertemuan menjadi 2 kali pertemuan. Oleh karena iu, model pembelajaran ceramah dan sistem catat lah yang digunakan oleh guru untuk mengejar materi yang cukup padat dan agar siswa dengan cepat memahaminya.

Idealnya sebelum menentukan model pembelajaran yang sesuai, terlebih dahulu guru harus memahami materi yang akan disampaikan sehingga guru dapat memilih model pembelajaran yang cocok digunakan untuk menyampaikan materi tersebut. apabila model pembelajarannya sudah tepat maka akan mempermudah peserta didik dalam memahami materi yang dipelajari;

(2) Problematika menjelaskan materi yaitu guru mengalami problematika dalam menjelaskan materi pembelajaran ketika mengubah kata kerja ke bentuk te atau ke bentuk ta, selain itu pada materi penggabungan kata seperti kata sifat dengan kata sifat atau kata sifat dengan kata benda, dan juga pada pembelajaran kanji. Hal tersebut terjadi dikarenakan karakteristik dan kemampuan siswa pada masing-masing kelas berbeda-beda. Pada jenjang kelas XI terdapat 3 kelas peminatan salah satunya adalah kelas ilmu bahasa dan budaya (IBB) yang mendapatkan pembelajaran bahasa Jepang. Masing-masing kelas memiliki karakteristik dan kemampuan yang berbeda-beda. Ketika guru menjelaskan materi bahasa Jepang tersebut di masing-masing kelas dengan cara mengajar yang sama, materi pembelajaran yang disampaikan di beberapa kelas sudah sesuai dengan tujuan pembelajaran dan alokasi waktu yang direncanakan, akan tetapi terdapat satu kelas yang memerlukan beberapa kali pertemuan untuk memahami materi tersebut. Oleh karena itu, materi-materi untuk pertemuan berikutnya menjadi tertinggal dan sulit untuk menyesuaikan dengan perencanaan yang dibuat. Guru sudah melakukan berbagai upaya untuk menjelaskan materi tersebut, seperti memberikan latihan secara terus menerus akan tetapi tidak ada peningkatan hasil belajar yang diperoleh siswa. Berdasarkan hal tersebut menunjukkan bahwa terjadi problematika guru dalam menjelaskan materi. Apabila guru menyesuaikan materi yang telah disampaikan terhadap kelas yang tertinggal, hal tersebut tentunya akan mengakibatkan materi yang harus selesai satu semester yang sesuai dengan tuntutan kurikulum menjadi tidak selesai sesuai dengan perencanaan yang dibuat, begitu pula sebaliknya jika kelas yang kurang tersebut menyesuaikan dengan tuntutan kurikulum mengakibatkan pembelajaran di kelas tersebut menjadi kurang kondusif.

Idealnya seorang guru bahasa Jepang dalam memberikan atau menyampaikan pelajaran bahasa Jepang harus mampu menguasai dan memahami materi yang berkaitan dengan bahasa Jepang dan memilih model dan metode pembelajaran yang sesuai dengan materi 
tersebut. Sehingga siswa mampu lebih cepat memahami materi yang disampaikan. Jika guru mengalami problematika terkait dengan materi yang akan disampaikan maka siswa akan kesulitan dalam menerima pelajaran yang disampaikan sehingga materi pelajaran selanjutnya akan terhambat;

(4) Problematika dalam menentukan sumber belajar yaitu guru dalam melaksanakan pembelajaran bahasa Jepang tidak menyediakan sumber belajar lain selain materi yang terdapat pada buku pegangan guru yang tersedia di sekolah. Hal ini dikarenakan keterbatasan jumlah buku yang seharusnya didapatkan sekolah oleh pemerintah yang belum sepenuhnya diberikan dalam memfasilitasi seluruh siswa dalam belajar. Untuk memfasilitasi siswa dalam pembelajaran di SMA Negeri 1 Banjar terdapat dua jenis buku ajar bahasa Jepang yakni buku Nihon go yang merupakan buku ajar kurikulum tingkat satuan pendidikan (KTSP) dan buku Kira-kira Nihon Go yang merupakan buku berbasis kurikulum 2013. Oleh karena peminat siswa terhadap bahasa Jepang di kelas IBB dikategorikan banyak dan jumlah buku ajar yang tersedia di sekolah dikategorikan kurang, sehingga tidak semua siswa memeroleh buku ajar tersebut sebagai pegangan siswa untuk belajar.

Idealnya dalam proses pembelajaran guru harus menggunakan sumber belajar yang lain selain buku pegangan siswa agar siswa mendapatkan informasi yang lebih lengkap selain di buku pegangan. Melalui sumber belajar tersebut akan dapat membantu peserta didik untuk memahami dan mempelajari materi yang akan disampaikan ataupun materi yang sudah disampaikan sebelumnya pada proses pembelajaran. Jadi apabila peserta didik sudah mempunyai pegangan ilmu dari sumber belajar yang lain dan membaca sebelum pelajaran berlangsung maka siswa akan lenih mudah memahami dan mengkuntruksi pembelajaran yang disampaikan. Disamping sumber belajar berguna bagi peserta didik, namun disisi lain sumber belajar juga memudahkan guru untuk menentukan model pembelajaran yang sesuai dengan materi tersebut.

Problematika pelaksanaan pembelajaran. Setelah guru menyusun perencanaan terkait pembelajaran yang akan dilaksanakan, langkah selanjutnya adalah melaksanakan pembelajaran yang telah direncanakan sebelumnya. Pada penelitian ini yang dilaksanakan di SMA N 1 Banjar terkait selama proses pembelajaran bahasa Jepang. Pada penelitian ini, data mengenai pelaksanaan pembelajaran bahasa Jepang diperoleh melalui wawancara dan observasi. Berdasarkan wawancara yang telah dilakukan kepada guru pengajar bahasa Jepang non kependidikan bahasa Jepang dan juga didukung dengan hasil observasi diperoleh informasi bahwa guru mengalami dua problematika dalam melaksanakan pembelajaran bahasa Jepang sebagai berikut;

(1) Problematika alokasi waktu yaitu bahwa guru mengalami problematika dalam menerapkan rencana pelaksanaan pembelajaran (RPP) yang dibuat khususnya pada alokasi waktu yang telah direncanakan. Berdasarkan hasil wawancara yang telah dilakukan, guru telah membuat perencanaan terkait alokasi waktu pada RPP namun guru tidak dapat menyesuaikan alokasi waktu yang telah direncanakan dengan yang diimplementasikan karena guru menyesuaikan dengan keadaan dan kondisi siswa di kelas pada saat pembelajaran. SMA Negeri 1 Banjar pada jenjang kelas XI terdapat 3 kelas peminatan khususnya peminatan ilmu bahasa dan budaya (IBB) yang mendapatkan pembelajaran bahasa Jepang. Masing-masing kelas memiliki siswa dengan karakteristik dan kemampuan yang berbeda-beda. Dalam hal ini guru menerapakan RPP yang sama ke semua kelas IBB khususnya kelas XI yang memiliki siswa dengan kemampuan yang berbeda-beda di masingmasing kelasnya. Hal tersebut mengakibatkan munculnya problematika terkait alokasi waktu terhadap 1 kelas yang kurang. Guru mengatakan bahwa guru harus menyelesaikan sekian materi pembelajaran bahasa Jepang dalam satu semester. Oleh karena itu guru mengalokasikan meteri yang diajarkan menjadi 4 materi dalam 1 kali pertemuan dengan durasi waktu 3 jam. Akan tetapi guru dalam menjelaskan materi sudah sesuai dengan yang dipaparkan pada RPP untuk di beberapa kelas yang diajarkan, akan tetapi terdapat 1 kelas yang memiliki kemampuan yang kurang jika dibandingkan dengan kelas yang lain. Hal ini ditunjukkan ketika guru memberikan materi, yaitu kelas tersebut tidak dapat menyelesaikan 4 materi dalam 1 kali pertemuan melainkan memerlukan 2x pertemuan untuk menyelesaikan materi tersebut. Sehingga kelas tersebut menjadi tertinggal dan tidak bisa menyesuaikan 
dengan kelas yang lain. Jika guru mengurangi materi menjadi 3 materi dalam $1 x$ pertemuan maka akan berpengaruh pada ketuntasan materi yang harus diselesaikan dalam 1 semester sesuai dengan kurikulum 2013. Sedangkan jika guru berpatok pada tuntutan kurikulum, maka kelas yang kurang akan tertinggal. Oleh karena itulah problematika alokasi waktu pun muncul;

Idealnya, Menurut Trianto (2011:170) pelaksanaan pembelajaran bahasa Jepang dilakukan dengan melalui tiga tahapan kegiatan, yaitu kegiatan pembuka/awal/pendahuluan, kegiatan inti, dan kegiatan penutup yangmana alokasi waktu untuk setiap tahapan adalah kegiatan pembuka lebih kurang 5-10\% waktu pelajaran yang disediakan. Kegiatan inti lebih kurang $80 \%$ dari waktu pelajaran yang telah disediakan, sedangkan kegiatan penutup lebih kurang $10-15 \%$ dari waktu yang disediakan;

(2) Problematika proses pembelajaran yaitu guru tidak bisa dalam menerapkan pendekatan scientific yang sesuai dengan kurikulum 2013. Hal ini dikarenakan pemahaman guru terhadap pendekatan scientific masih kurang, dan juga guru kurang mampu dalam menerapkan sintak-sintak pembelajaran pada pendekatan scientific sepenuhnya sebagaimana yang diharapkan kurikulum 2013. Pada proses pembelajaran berbasis scientific yang terdiri atas pembelajaran 5M yaitu M1 (mengamati), M2 (menanya), M3 (Mengumpulkan informasi/mencoba), M4 (mengasosiasi), dan M5 (mengkomunikasikan) guru hanya melaksanakan M1 dan M2 sedangkan pada tahap M3, M4, dan M5 tidak dapat dilaksanakan. Hal tersebut terjadi karena guru kurang memahami komponen-komponen yang terdapat dalam pembelajaran scientific khususnya pada kegiatan M3, M4 dan M5 Pendekatan scientific merupakan pendekatan yang lebih menekankan pada pembelajaran yang mengaktifkan siswa. Pendekatan ini paling tidak melibatkan tiga model pembelajaran, diantaranya problem based learning, project based learning, dan discovery learning. Akan tetapi faktanya guru dalam melakukan kegiatan proses pembelajaran di dalam kelas lebih didominasi dengan mencatat semua materi yang diberikan, sehingga kegiatan untuk melakukan latihan-latihan di kelas menjadi kurang. Seharusnya dengan pemberian latihan guru dapat menerapkan kegiatan M3, M4, dan M5 namun karena kurangnya latihan, tahap tersebut tidak dapat dilaksanakan sehingga sangat sulit untuk menerapkan pembelajaran scientific pada proses pembelajaran.

Sesuai dengan kurikulum 2013 guru dalam proses pembelajaran dapat mengimplementasikan pendekatan scientific yang terdiri atas pemahaman belajar pokok (5M) yaitu mengamati, menanya, mengumpulkan informasi, mengasosiasi, dan mengkomunikasikan. Selain itu sesuai kurikulum 2013 media pembelajaran merupakan salah satu elemen penting dalam proses belajar mengajar, penggunaan media pada setiap proses pembelajaran telah menjadi sebuah tuntutan atau bahkan keharusan bagi setiap guru. Dengan adanya media pembelajaran guru dapat membangkitkan motivasi dan minat siswa serta dapat membantu siswa mengingat pemahaman terkait materi yang akan disampaikan. Selain itu penggunaan media pembelajaran juga sejalan dengan konsep paradigma pembelajaran dalam student centred learning, dimana guru berperan sebagai mediator dan fasilitator, dan tidak lagi berperan sebagai penyampai informasi atau sebagai satu-satunya sumber pengetahuan.

Dalam proses pembelajaran, selain guru menyusun rencana pelaksanaan pembelajaran (RPP) dan melaksanakan proses pembelajaran, disamping itu guru juga melakukan evaluasi/penilaian terhadap siswa untuk mengetahui sejauh mana perkembangan siswa. Pada penelitian ini meneliti problematika penilaian pembelajaran oleh guru non kependidikan bahasa Jepang melalui dua metode pengambilan data yaitu observasi dan wawancara. Berdasarkan penyajian data hasil wawancara dan observasi diperoleh informasi bahwa guru mengalami dua problematika dalam melaksanakan pembelajaran bahasa Jepang sebagai berikut;

(1) Problematika penilaian berbasis proses yaitu guru pengajar bahasa Jepang mengalami problematika dalam melaksanakan penilaian berbasis proses. Hal tersebut terjadi dikarenakan guru mengalami kesulitan dalam memanejemen waktu ketika melaksanakan penilaian aktivitas siswa keseharian dan efektifitas pembelajaran secara keseluruhan dalam mencapai tujuan pembelajaran dengan waktu yang terbatas sedangkan aspek yang dinilai 
pada proses pembelajaran pun banyak disamping itu materi pembelajaran yang harus disampaikan kepada siswa sangat padat. Guru dituntut harus menuntaskan materi pembelajaran yang sangat padat namun disisi lain guru harus menilai aktivitas siswa dari berbagai aspek hal tersebutlah yang menyebakan guru mengalami problematika dalam melaksanakan evaluasi penilaian yang berbasis proses dalam pembelajaran. Selain guru mengalami kendala memanajemen waktu dalam penilaian berbasis proses, disamping itu guru juga mengalami problematika dalam meningkatkan efektifitas pembelajaran karena guru kurang memberikan latihan kepada siswa padahal belajar bahasa Jepang harus diimbangi dengan latihan namun berdasarkan faktanya guru dalam proses pembelajaran lebih banyak mencatat dan guru lebih banyak menggunakan metode ceramah. Hal tersebut juga memicu permasalahan bagi guru dalam melaksanakan penilaian berbasis proses karena tidak efektifnya proses pembelajaran di kelas.

Berdasarkan hal tersebut idealnya penilaian berbasis proses harus dilaksanakan oleh semua guru dalam proses pembelajaran hal ini bertujuan untuk mengetahui kegiatan belajar mengajar terutama efesiesni, keefektifan dan produktivitas dalam mencapai tujuan pembelajaran. Dimensi penilaian berbasis proses dalam proses belajar mengajar berkenaan dengan komponen-komponen proses belajar-mengajar seperti tujuan pembelajaran, metode, bahan pengajaran, kegiatan belajar, kegiatan mengajar guru mengajar dengan harapan untuk mengetahui kelemahan peserta didik salama melakukan kegiatan mengajar, mengetahui ketercapaian siswa dalam kegiatan belajar dan sebagai alat untuk mengetahui perkembangan belajar siswa. Namun berdasarkan fakta yang ditemukan di SMA N 1 Banjar pelaksanaan penilaian berbasis proses belum dapat dilaksanakan sesuai dengan aturan yang ada hal ini terjadi karena kurang manajemen waktu dan kurangnya efektifitas pembelajaran khususnya pemberian latihan dalam proses pembelajaran.

(2) Problematika penilaian sikap yaitu guru telah melaksanakan penilaian sikap dalam proses pembelajaran namun dalam aplikasinya terdapat problematika yang dialami sehingga dalam melaksanakan penilaian sikap guru belum maksimal dalam melaksanakannya. Dalam melaksanakan penilaian sikap terdapat 4 teknik atau bentuk penilaian sikap diantaranya; observasi, penilaian diri, penilaian antar pesera didik dan jurnal. Berdasarkan data yang diperoleh guru mengalami kesulitan dalam melaksanakan penilaian kompetensi sikap dengan teknik observasi. Permasalahannya teknik observasi yakni kadang perilaku siswa tidak terekam apabila guru berhalangan hadir, karena untuk observasi memerlukan pengamatan secara langsung oleh guru disamping itu guru harus menilai secara detail sikap siswa dalam proses pembelajaran. Selain itu guru merasa kurang maksimal dalam melaksanakan penilaian diri. Hal ini disebabkan karena siswa merasa kesulitan dalam menjawab penilaian diri dan siswa tidak memahami bahwa dalam menjawab penilaian diri harus jujur dan apa adanya. Disamping itu guru harus membagi waktu antara penyampaian materi, pemberian tugas, dan proses evaluasi. Hal inilah yang menyulitkan guru dalam melaksanakan penilaian sikap siswa. Sebagaimana diketahui bahwa penilaian sikap siswa harus dilaksanakan secara individu dan langsung bertatap muka. Sehingga, keterbatasan waktu yang dimilki menjadi penghambat bagi guru. Selain itu poin pada penilaian sikap terlalu banyak, sehingga menghabiskan waktu dalam memilah aspek tersebut yang mengakibatkan pembelajaran dalam satu hari itu tidak semuanya tuntas dilaksanakan.

Faktor kedua adalah jumlah siswa yang banyak dalam satu kelas. Guru harus mengamati 35 siswa dalam sekali pertemuan. Sehingga, guru harus benar-benar membagi waktunya. Guru yang hanya berjumlah satu orang harus mengamati 35 orang siswa dalam waktu yang bersamaan. Kemudian item penilaian pun terlalu rumit per sub tema dan tema dengan memperhatikan KD-KD setiap mapel. Pada aspek penilaian sikap juga dirasakan sangat sulit karena guru tidak mungkin bisa memantau sekian banyak anak didik. Idealnya berdasarkan kurikulum 2013 guru harus melakukan 2 penilaian sikap siswa yaitu sikap spritual dan sikap social namun karena kendala waktu dan jumlah siswa terlalu banyak maka penilaian sikap tidak dapat dilaksanakan sesuai dengan aturan yang ada. 


\section{Simpulan dan Saran}

Berdasarkan pada hasil penelitian dan pembahasan, maka simpulan dari penelitian ini adalah guru bahasa Jepang di SMA Nederi 1 Banjar mengalami beberapa problematika sebagai berikut; (1) Problematika model pembelajaran yaitu guru mengalami problematika dalam menentukan metode atau model pembelajaran yang tepat untuk menjelaskan materi ke siswa,

(2) Problematika menjelaskan materi yaitu guru mengalami problematika dalam menjelaskan materi pembelajaran ketika mengubah kata kerja ke bentuk te atau ke bentuk ta, selain itu pada materi penggabungan kata seperti kata sifat dengan kata sifat atau kata sifat dengan kata benda, dan juga pada pembelajaran kanji,

(3) Problematika sumber ajar yaitu guru dalam melaksanakan pembelajaran bahasa Jepang tidak menyediakan sumber belajar lain selain materi yang terdapat pada buku pegangan guru yang tersedia di sekolah,;

(4) Problematika memenejemen waktu yaitu guru mengalami problematika dalam menerapkan rencana pelaksanaan pembelajaran (RPP) yang dibuat, khususnya pada alokasi waktu yang telah direncanakan;

(5) Problematika proses pembelajaran yaitu guru mengalami problematika pada kegiatan pembelajaran yakni guru tidak bisa menerapkan pembelajaran scientific pada proses pembelajaran;

(6) Problematika penilaian berbasis proses yakni guru mengalami kendala dalam peniaian berbasis proses yang dilakukan kurang maksimal; dan

(7) Problematika penilaian sikap yakni guru mengalami kendala dalam penilaian sikap.

\section{Daftar Pustaka}

Peraturan Pemerintah Republik Indonesia No.74 tahun 2008 tentang Guru. Jakarta: Departemen Pendidikan Nasional.

Sugiyono. 2011. Metode Penelitian Kuantitatif Kualitatif dan $R \& D$ Cetakan Ke-13. Bandung: Alfabeta.

Undang-Undang Republik Indonesia Nomor 14 Tahun 2005 Tentang Guru dan Dosen. Jakarta: Departemen Pendidikan Nasional.

Undang-Undang Republik Indonesia Nomor 20 Tahun 2003 Tentang Sistem Pendidikan Nasional. Jakarta: Departemen Pendidikan Nasional. 